\title{
A participatory ecodesign framework to address both environmental and economic dimensions in viticulture at farm scale
}

\author{
Aurélie Perrin ${ }^{1} \cdot$ Magdalena Czyrnek-Delêtre ${ }^{1} \cdot$ Maha Ben Jaballah $^{2} \cdot$ Anthony Rouault $^{1} \cdot$ Hayo M. G. van der Werf ${ }^{3}$. \\ Mohamed Ghali ${ }^{2} \cdot$ Annie Sigwalt $^{2} \cdot$ Christel Renaud-Gentié $^{1}$ (1)
}

Accepted: 20 September 2021 / Published online: 8 February 2022

(c) The Author(s) 2022

\begin{abstract}
There is an urgent need for agriculture in general, and for viticulture in particular, to reduce their impacts on the environment. Doing so requires an approach that supports transitioning to more environmentally friendly practices. Involving farmers and agricultural advisors is key to lifting technical, economic, and social barriers to this transition. Participatory methods can help to consider specific contexts and concerns, but few suitable tools are available. We developed a methodological framework to address both environmental and economic dimensions at the field and farm scales in three participatory ecodesign workshops with winegrowers. We applied our framework to the ecodesign of pathways of technical operations in the Middle Loire Valley, France. The first two workshops focused on the field scale, and group interactions were facilitated using a serious game and a "live" assessment of the environmental performance of the ecodesigned system. The third workshop focused on implementation at farm level. The aggregated environmental impact of the ecodesigned farm decreased by $4 \%$, while the economic performance of its four pathways of technical operations improved. We showed that combining environmental and economic assessment tools, suitable for use in participatory workshops, addresses most mechanisms for and barriers to changing practices at the farm scale. The typology of activities at the farm scale allows farm characteristics and the diversity of production systems to be represented in the ecodesign without over-complicating the process. The use of farm maps takes advantage of the collective expertise of the group and increases participant involvement. This process highlighted the need to continue to extend the scope and criteria of ecodesign to decrease environmental impacts even more. Here, we show for the first time the need to quantify the influence of a farm's environmental practices on its economic performance to reduce the perception of risk and facilitate adoption of these practices.
\end{abstract}

Keywords Economic assessment · Environmental assessment · Farm activity typology $\cdot$ Farm ecodesign · Life cycle assessment $\cdot$ Participatory workshop $\cdot$ Protected designation of origin $\cdot$ Risk perception $\cdot$ Vineyard management

\section{Introduction}

Viticulture plays an important role in culture and landscapes in many producing countries (Stanco and Lerro 2020; Winkler et al. 2017; Gullino and Larcher 2013); however, it can also generate environmental impacts (Christ and Burritt

Christel Renaud-Gentié

c.renaud@groupe-esa.com

1 USC 1422 GRAPPE, INRAE, Ecole Supérieure d'Agricultures, SFR 4207 QUASAV, 55 Rue Rabelais, BP 30748, 49007 Angers CEDEX 01, France

2 LARESS Research Unit, Ecole Supérieure d'Agricultures, 55 Rue Rabelais, BP 30748, 49007 Angers CEDEX 01, France

3 UMR SAS, INRAE, Institut Agro, 35000 Rennes, France
2013) as biodiversity loss (Paiola et al. 2020), erosion (Martínez-Casasnovas et al. 2012), soils and water pollution (Mackie et al. 2012; Herrero-Hernández et al. 2020; Pompermaier et al. 2021), or greenhouse gas emissions (Rugani et al. 2013; Beauchet et al. 2019). An increasing pressure is put on the winegrowers to reduce viticulture's impacts on the environment by citizens and by marketers related to consumers attempts (Stanco and Lerro 2020; Nazzaro et al. 2016; Tait et al. 2019). Moreover, recent and rapid changes in EU or national regulations to ban more pesticides, increase quality standards, and restrict specific practices (e.g., not apply pesticides to sensitive areas) as well as public policies encouraging decrease of pesticide use, or environmental certification like the Ecophyto program in France, compel wine growers to change their practices. 
However, the top-down approach of public policies ignores the specific characteristics and diversity of production systems. There are technical, economic, and social barriers to changing practices (Jourjon et al. 2016; Asfaw and Neka 2017). The lack of farmers' involvement in the transition processes defined by public policies is one barrier to change (Liu et al. 2018). Consequently, approaches are needed to support a change to more environmentally friendly practices that involves farmers and agricultural advisors (Martin et al. 2013) and uses participatory methods to consider their specific contexts (Lacombe et al. 2018; Meynard et al. 2012). To be effective, such approach should include technical, social, and economic dimensions. Many tools are available to assess economic or environmental performances at field, farm, or regional spatial scales. However, each of these scales has limits to its ability to inform changes in practices, and few tools are suitable for use in participatory approaches (Sala et al. 2015; Renouf et al. 2018). Tools also differ in terms of the purpose of the evaluation, the productions evaluated, the nature of the data collected, the type of indicators (pressure, state, simple, aggregated), the rating scales and the threshold values, etc. (Delmotte et al. 2009). As well, evaluating economic performance mobilizes several methods and indicators and often considers only the financial indicators. For example, some studies mobilize indicators such as gross and net margins, resources costs, and farm income to evaluate the economic performance (Calsamiglia et al. 2018; Blasi et al. 2016). Others mobilize the technical-economic efficiency defined by the difference between the maximum output determined by the production frontier and the necessary production factors (minimum inputs) (Boussemart and Dervaux 1994; Alem et al. 2018).

However when evaluating environment friendly practices, one should consider resource sustainability, long-term profitability, and generational transferability of farms in order to take into account interactions and dynamics that may exist at the farm level.

Ecodesign refers to the integration of environmental aspects into product design, with the aim of mitigating environmental impacts throughout the product's life cycle (European Commission 2009). As such, it considers how product design influences environmental impacts, not only in the production phase, but also in the upstream procurement of inputs, downstream operational and use phases, and end of life disposal phases. These information should be used in the design or redesign of production systems in order to minimize environmental impact while satisfying all other characteristics of the design core. Ecodesign is heavily informed by the quantification of environmental impacts over the product's lifecycle using LCA. LCA has been applied to agricultural systems and products to highlight the large contribution of the agricultural stage to the environmental impacts of food and beverages (Roy et al. 2009). It has also been used to screen promising impact mitigation strategies in agricultural systems (Rouault et al. 2020) and supply chain logistics (Perrin et al. 2017). Participatory ecodesign workshops consist in gathering farmers to discuss practice changes related to environmental performances based on an initial diagnosis (often) performed with the life cycle assessment methodology (Fig. 1). We show in a previous study that such approach that address the field scale can support changes in practices in viticulture (Rouault et al. 2016). However, focusing on vine management in a single field for 1 year limits the degree of innovation in ecodesigned systems and precludes addressing certain mechanisms and barriers, including economic issues. This study aims to answer the following research question: How can we bring more innovation and overcome social and economic barriers to changing practices through participatory eco design workshops? We developed a methodological framework to address both environmental and
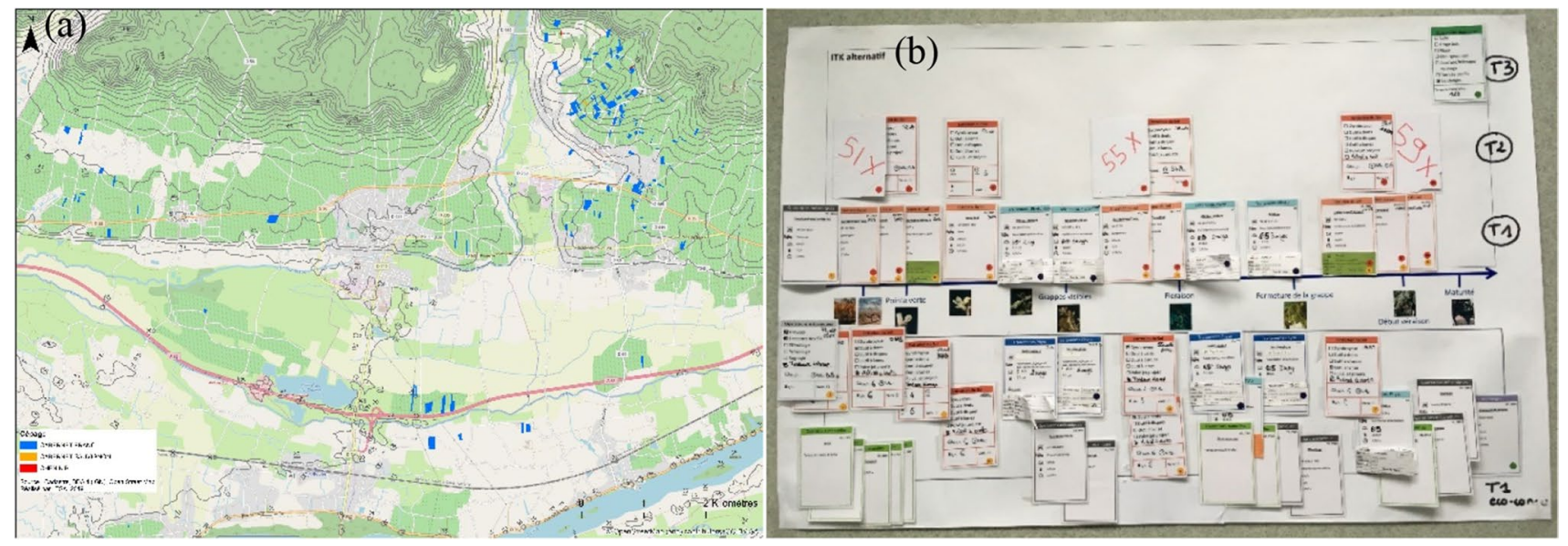

Fig. 1 Tools used to moderate the participatory ecodesign workshop at farm scale: (a) a map displaying fields and topographical information and (b) a board displaying pathways of technical operations and crop development stages. 
economic dimensions at the farm scale during participatory ecodesign workshops with winegrowers (Fig. 1). In this article, we aim to show that:

- Combining environmental and economic assessment tools, suitable for use in participatory workshops, allows most mechanisms for and barriers to changing practices to be addressed at the farm scale.

- Identifying types of farm activities and physical characteristics of fields allows specific characteristics of farms and the diversity of production systems to be represented in ecodesign at the farm scale.

- Using farm maps in participatory workshops for ecodesign at the farm scale allows to take advantage of the collective expertise of the group and increases participant involvement.

\section{Materials and methods}

\subsection{Combining participatory workshops and multidisciplinary assessment tools in ecodesign of viticulture at the farm scale}

The framework described in this article (Fig. 2) has been improved from a previous study which focused on ecodesign of one pathway of technical operations (PTO) within a farm
(Rouault et al. 2020). Ecodesign workshops were organized with groups of farmers, which preferably are used to work together, supported by their usual advisors. Researchers play different roles sequentially or simultaneously during the workshop: facilitators to ease discussions and support the group in their progression, environmental experts, or tool managers. This ecodesign process, composed of two successive workshops, was based on several case studies taken from participants' farms for which an initial environmental diagnosis was performed. During the first workshop, the researchers ensured that participants understood LCA results sufficiently well and encouraged them to identify alternative operations to reduce impacts of viticulture practices at the field scale. During the second workshop, participants redesigned the initial vineyard management practices by removing or adding operations, replacing them with alternative operations identified during the first workshop, and/or adjusting the parameters of these operations (e.g., tractor speed, duration of use, or fuel consumption and doses or recycling rate of pesticide). During this workshop, group interactions were facilitated using a serious game and a "live" LCA calculation of the ecodesigned system built by the participants (Rouault et al. 2020). The group's objective was to use the winegrower case study to redesign a new PTO that was more environmentally friendly and met the winegrower's criteria. These elements and their role in the approach are described and discussed in detail by Rouault (2019).
Fig. 2 Diagram of the approach applied and relations to previous studies (gray boxes).

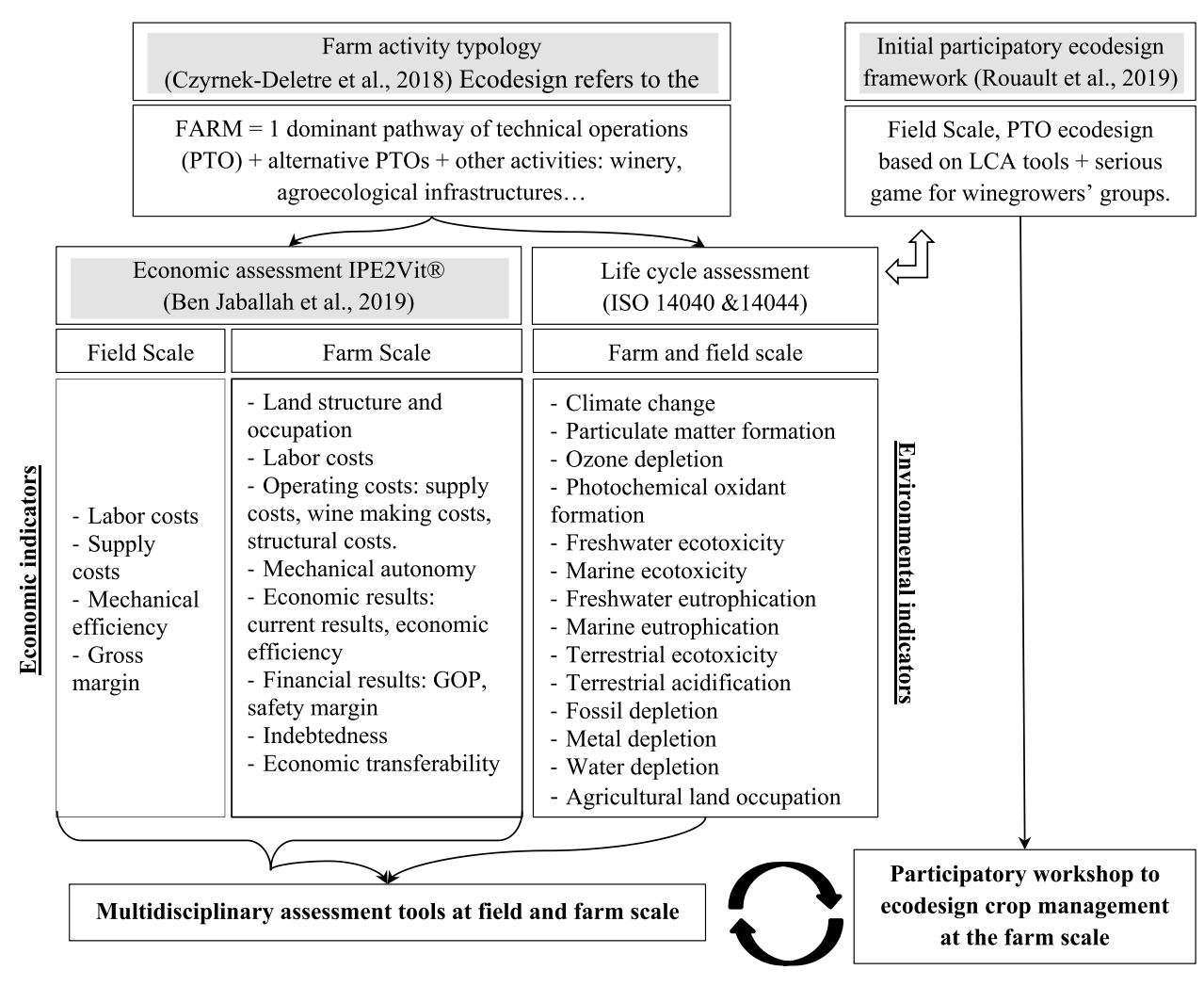


We improved this framework to bring more innovation and overcome social and economic barriers to changing practices. Changes have been oriented by results from a two-step survey process launched in parallel with participatory workshops. The survey aimed to (i) precisely know the reasons why farmers were either positive or negative towards ecological innovations and (ii) to reveal who they were discussing these innovations with. Twelve semi-directive interviews have first been conducted and recorded with winegrowers to analyze their ways of thinking ecological innovations at plot or farm scale. These innovations had been chosen for their LCA-positive impact and could occur during the vegetative cycle of the vine. Such innovations were (i) trellising with acacia wooden stakes, (ii) investment in low fuel use tractor, (iii) choice of non-carcinogenic, mutagen, reprotoxic pesticide products, (iv) choice of organic rather than chemical fertilizers, (v) soil maintenance of vine inter-rows by mechanical means or by grazing, (vi) coupling of soil and foliage maintenance operations, (vii) use of a low-drift sprayer for pesticide application, and (viii) choice of manual rather than mechanical harvest. Part of the questions was addressing the relationship farmers have with other farmers, with their employees, with advisors, or with non-professional relatives. The corpus analysis enabled us to then create a questionnaire, pursuing the same objectives, which was addressed to 90 winegrowers in face-to-face interviews. These surveys took place in Loire-Atlantique, Maine-et-Loire, and Indre-et-Loire departments (Loire valley) and were sized according to the characteristics of the winegrowers' economic systems.

A third workshop, with the same group of farmers and agricultural advisors as before, was added to the initial framework to enlarge the ecodesigned process at the farm scale. Environmental performances of the system ecodesigned during the second workshop were presented, as were the environmental and economic performances at the farm scale for the types of PTO and other activities. A map of vine fields and their respective types of PTO was used to identify opportunities and constraints for changing practices at the farm scale (e.g., fields used, paths, access roads, houses proximity). Farmers were then asked to discuss whether the ecodesigned system could be applied at the farm scale, if yes, to which extent and if not, what changes would be required. At the end of the workshop, performances of the ecodesigned farm from an environmental and economic point of view were discussed to highlight difficulties and the remaining constraints to exploring significant changes in practices.

The typology of farm activities developed by CzyrnekDeletre et al. (2018) was used to facilitate application of the two tools for economic and environmental assessment to inform changes in practices at the farm scale. The typology consists in characterizing the dominant production system and the main alternative production systems, which could be subdivided according to the main factors that influence their environmental performances, such as topography and the pedoclimatic context. The typology describes other farm activities in less detail (i.e., only inputs and outputs, without details of the operations or biophysical mechanisms involved). While the dominant production system can be considered the average system, the alternative productions systems differ for one or two factors: it may produce a minor wine type (i.e., not the main wine type produced in the farm) or correspond to a significantly different but minor soil type (i.e., not the main soil type of the farm).

\subsection{Multidisciplinary assessment tools at field and farm scales}

\subsubsection{Economic assessment for farm ecodesign}

To evaluate the impacts of changes in practices on economic performance, we used the tool IPE2Vit ${ }^{\circledR}$ ("Indicators of Economic Performances at field and farm scales in VITiculture" in French) (Ben Jaballah et al. 2019). IPE2Vit is a decision support tool and a technical-economic simulator. Winegrowers, groups of producers, and agricultural advisors can use it to study impacts of changes in practices on economic performance at field and farm scales.

IPE2Vit can be used to assess the economic performance of a farm (self-assessment) to identify ways to increase performance by changing practices (piloting), to measure progress in performance in the field and on the farm (selfassessment). To quantify economic performance, IPE2vit uses indicators from the literature and includes a new indicator called "mechanical autonomy," which reflects a farmer's ability to use existing equipment to perform new practices. It also assesses the need to invest in new equipment.

This choice of indicators to define economic performance was adapted to consider the change in scale (from field to farm). Economic performance appears to differ according to the scale of analysis and to its composite dimensions and components. The economic literature shows that a farm's economic performance is not a simple aggregation of the economic performances of its fields. Economic decisions at the farm scale, such as changes in practices or investment in equipment, depend on all farm activities, including winemaking and marketing.

The IP2vit tool provides indicators at both scales for a given farm. At the field scale, the tool provides indicators for the costs of labor, vineyard inputs, and fuel, as well as the gross margin. Additional indicators (safety margin, gross operating surplus, and loan repayment) are calculated at the farm scale and are compared to field-scale indicators. The calculation method is transparent, which facilitates a systematic approach. The tool calculates 
scores from the indicators, which are then aggregated into components and an overall indicator. Indicators and components have different weights in the definition of economic performance. At the farm and field scales, the overall indicator (i.e., "economic performance") results from the weighted sum of the components (Ben Jaballah et al. 2019).

\subsubsection{Environmental assessment tools for farm ecodesign}

Environmental assessment was based on LCA, the method most widely used to assess resource depletion issues and environmental and health impacts caused by production of agricultural products (van der Werf et al. 2020). At the field scale, LCA was performed using tools to assess PTO in detail (Rouault et al. 2020). The tools' detail results down to individual operations and aggregate impact categories using the CONTRA Qualenvic approach (Beauchet 2016). At the farm scale, LCA of vineyard management itself was performed with the same level of detail as that at the field scale. For other farm activities, LCA was performed in less detail. In both cases, foreground inventory data were collected through interviews with farmers. At the field scale, detailed inventories were based on traceability documents available on farm (management software or written notes), while less detailed inventories for other farm activities were based mainly on bills and accounting documents. Expert data were used to estimate fuel consumption (when not known by the farmer), pesticides, fertilizers, and equipment characteristics. Production and transport of machinery and inputs came from the Agribalyse v.1.1 and ecoinvent v.2.2 databases. On-field emissions for pesticides, phosphorus, nitrogen $\left(\mathrm{NO}_{3}, \mathrm{~N}_{2} \mathrm{O}, \mathrm{NO}_{\mathrm{x}}\right)$, heavy metals, and fuel (NMVOC, $\mathrm{CO}, \mathrm{NO}_{\mathrm{x}}$ ) were estimated using the same emission models as in Rouault et al. (2020). Environmental impacts were calculated using the ReCiPe Midpoint (H) v1.12 method (Goedkoop et al. 2009). All of its impact categories were included except for human toxicity, ionizing radiation, urban land occupation, and natural land transformation, which were considered less relevant among the impacts of wine production (Beauchet 2016). In addition, the freshwater ecotoxicity impact category from ReCiPe Midpoint was replaced with the freshwater ecotoxicity impact category from USEtox ${ }^{\mathrm{TM}} \mathrm{v} \cdot 1.04$. USEtox $^{\mathrm{TM}}$ is a consensus model that represents the best practice for characterizing toxic impacts of chemicals in LCA (Renaud-Gentié et al. 2014) and is the most consistent with the PestLCI2.06 model, used to calculate emissions from pesticide applications. To simplify presentation of results, weighting factors from the CONTRA Qualenvic approach were used to aggregate impacts (Table 2).

\subsection{General characteristics and vineyard management typology}

The case study was used in a workshop with eight winegrowers from the Middle Loire Valley supported by two advisors. Half of the participants belonged to the local winegrowers' cooperative, while the other half were engaged in a private network of winegrowers that promote environment friendly practices. The farm studied was managed to reduce the amount of pesticides applied. Its main activity was grape production, with on-site winemaking and bottling. The grape production area covered 47 ha on 120 fields distributed within $10 \mathrm{~km}$ of the farm headquarters. A total of $2500 \mathrm{hl}$ of wine was produced in 2017, with six types of wine made from Cabernet Franc and Chenin Blanc varieties.

We distinguished four types of PTO on the farm (Table 1). The fist type (PTO 1) dominated, covering more than $51 \%$ of the farm's total area with the same PTO on calcareous clay soils mechanically weeded in every other inter-row and grass covered in the others. In contrast, the second type (PTO 2) had an alluvial soil; consequently, its soil management differed from PTO 1 and 3 because gravelly soils are not suited for inter-row grass cover as it competes for water. The third type (PTO 3) differed from PTO 1 in the type of wine produced-sparkling wine-which need selective manual harvest instead of the mechanical harvest used in the other types. The last type (PTO 4) had the same soil type and management practices as PTO 1 but differed only in that its steeper slope increased soil erosion, which increased certain emissions (nitrate, phosphorus, and heavy metals). The PTO that was ecodesigned during the second workshop (PTO 1eco) differed from PTO 1 in that mechanical weeding replaced two herbicide applications under vine rows. It resulted in fewer soil management operations in PTO 1eco because row mechanical weeding operation was coupled with inter-row mechanical weeding in a same operation. In addition, the sprayer was equipped with a recycling panel for the first two applications, which decreased pesticide application rates, and all CMR (carcinogenic, mutagenic, or toxic for reproduction) pesticides were replaced with non-CMR pesticides.

To assess changes in economic performances due to changes in practices, only three production types were used to characterize the farm's grape production area: PTO $1+4$ combined (because they had the same field-scale economic performances), PTO 2, and PTO 3. 
Table 1 Main characteristics of the four current pathways of technical operations (PTO 1 to PTO 4) and the first ecodesigned pathway of technical operations (PTO 1eco). Bold text indicates characteristics that differed from those of other types.

\begin{tabular}{|c|c|c|c|c|c|}
\hline Characteristic & PTO 1 & PTO 1eco & PTO 2 & PTO 3 & PTO 4 \\
\hline Wine type(s) & Red, white, rosé & Red, white, rosé & Red, white, rosé & Sparkling & Red, white, rosé \\
\hline Area (ha) & 24 & 24 & 17 & 2 & 4 \\
\hline Soil type & Calcareous clay & Calcareous clay & Alluvial & Calcareous clay & Calcareous clay \\
\hline Calcium carbonate content $(\%)$ & 26.3 & 26.3 & 9.7 & 26.3 & 26.3 \\
\hline Slope $(\%)$ & $<2$ & $<2$ & $<2$ & $<2$ & 05-10 \\
\hline Erosion (t/ha/year) & 4.4 & 4.4 & 7.1 & 4.4 & 32.5 \\
\hline Pesticide applications/year & 8 & 6 & 8 & 8 & 8 \\
\hline Of which herbicides & 2 & 0 & 2 & 2 & 2 \\
\hline Of which with recycling panels & 0 & 2 & 0 & 0 & 0 \\
\hline Soil management operations /year & 10 & 7 & 8 & 10 & 10 \\
\hline Row soil management & Herbicide & Tilled & Herbicide & Herbicide & Herbicide \\
\hline Inter-row soil management & $\begin{array}{l}\text { Grass covered/ } \\
\text { tilled on alter- } \\
\text { nate row }\end{array}$ & $\begin{array}{l}\text { Grass covered/ } \\
\text { tilled on alter- } \\
\text { nate row }\end{array}$ & $\begin{array}{l}\text { Herbicide/tilled } \\
\text { on alternate } \\
\text { row }\end{array}$ & $\begin{array}{l}\text { Grass covered/ } \\
\text { tilled on alter- } \\
\text { nate row }\end{array}$ & $\begin{array}{l}\text { Grass covered/ } \\
\text { tilled on alter- } \\
\text { nate row }\end{array}$ \\
\hline Harvest & Mechanical & Mechanical & Mechanical & Manual & Mechanical \\
\hline Mechanical operations/year (total number) & 26 & 23 & 24 & 26 & 26 \\
\hline Mechanical work (h/ha/year) & 28 & 26 & 32 & 35 & 28 \\
\hline Manual work (h/ha/year) & 91 & 91 & 91 & 211 & 91 \\
\hline
\end{tabular}

\section{Results and discussion}

\subsection{Main results about the farmers' social networks and their disposition to technical change}

The survey results brought contrasting lessons, both on farmers' ways of thinking and discussion networks. First because the proposed technical innovations either dealt with a plot or a farm scale approach, inducing a more or less important design of the work organization on the farm. For example, choosing untreated and local acacia wood trellising stakes, rather than metal ones, can be introduced and experimented in one plot and extended to other plots over time. The change is much more important when it comes to buy a new and expensive type of tractor, which technology allows less use of fossil resources (fuel). It is therefore important to precisely analyze each farmer's work logic to be able to discuss the opportunity of introducing such or such innovation. Second, because the farmer discusses the interest of each type of innovation with rather distinctive communication networks. The number of discussion links and the people profiles in each individual farmer's network differed. Some innovations seemed to be little discussed, such as trellising, grazing inter-rows, or harvest method (in this latter case mainly because winegrowers have to respect their PDO set of rules to valorize their wines). In the case of the choice of a more ecological tractor, the reasons which prevailed relate much more to the working comfort allowed by this type of tractor (very important stake vis-à-vis the maintenance of qualified tractor-drivers on the farm) than to ecological aspect of this tractor. We here clearly see how the relationship with the work team impacts the farmer's decision. About fertilization and phytosanitary treatments, farmers spontaneously quoted agricultural advisors, either in individual or collective advising relationships. These advisors can either work for private companies or associations, or semi-public organizations. This refers to the major efforts these last years to try and reduce the use of these products by farmers, through successive agricultural policies launched such as Ecophyto plans (French-ministry-of-agriculture 2021). On this topic though, another type of link may interfere, involving non-professional interlocutors such as family or customers, when it specifically comes to phytosanitary products harmfulness for human health. These conclusions led us to change the scale of the workshop and introduce a map.

\subsection{Performances of the ecodesigned dominant type (PTO 1)}

\subsubsection{Environmental performances of the case study}

Environmental performances of the whole farm were presented in the last workshop (Table 2). Wine production contributed up to $56 \%$ of the terrestrial acidification and $54 \%$ of the metal depletion of the farm, mainly due to the production of glass bottles. Wine production contributed $32 \%$ of the whole farm's aggregated impact, while PTO 1 contributed $34 \%$ of it. PTO 1 contributed up to $50 \%$ of the freshwater ecotoxicity (due to pesticide 
Table 2 Environmental and economic assessment of the vineyard at the farm and the field scale and variations at the field scales due to ecodesign. PTO 1 to PTO 4: pathways of technical operations. *Val- ues for the winery and loan repayment are expressed for the whole farm and not per hectare.

\begin{tabular}{|c|c|c|c|c|c|c|c|c|}
\hline & \multicolumn{2}{|c|}{$\begin{array}{l}\text { Initial assessment at } \\
\text { farm scale }\end{array}$} & \multicolumn{4}{|c|}{ Initial assessment at field scale } & \multicolumn{2}{|c|}{$\begin{array}{l}\text { Ecodesign at field } \\
\text { scale }\end{array}$} \\
\hline & Farm & Winery* & PTO 1 & PTO 2 & PTO 3 & PTO 4 & PTO 1eco & $\begin{array}{l}\text { Reduction } \\
\text { vs. PTO } 1\end{array}$ \\
\hline \multicolumn{9}{|l|}{ Environmental assessment } \\
\hline Climate change (CC, kg CO2 eq) & $2.2 \mathrm{E}+03$ & $5.0 \mathrm{E}+04$ & $1.2 \mathrm{E}+03$ & $1.2 \mathrm{E}+03$ & $1.1 \mathrm{E}+03$ & $1.2 \mathrm{E}+03$ & $1.1 \mathrm{E}+03$ & $9 \%$ \\
\hline $\begin{array}{l}\text { Particulate matter formation } \\
\text { (PMF, kg PM10 eq) }\end{array}$ & $5.2 \mathrm{E}+00$ & $1.2 \mathrm{E}+02$ & $2.6 \mathrm{E}+00$ & $2.9 \mathrm{E}+00$ & $2.9 \mathrm{E}+00$ & $2.6 \mathrm{E}+00$ & $2.4 \mathrm{E}+00$ & $9 \%$ \\
\hline Ozone depletion (OD, kg CFC-11 eq) & $2.6 \mathrm{E}-04$ & $5.4 \mathrm{E}-03$ & $1.5 \mathrm{E}-04$ & $1.5 \mathrm{E}-04$ & $1.4 \mathrm{E}-04$ & $1.5 \mathrm{E}-04$ & $1.1 \mathrm{E}-04$ & $28 \%$ \\
\hline $\begin{array}{l}\text { Photochemical oxidant formation } \\
\text { (POF, kg NMVOC) }\end{array}$ & $1.3 \mathrm{E}+01$ & $2.2 \mathrm{E}+02$ & $8.0 \mathrm{E}+00$ & $8.8 \mathrm{E}+00$ & $9.2 \mathrm{E}+00$ & $8.0 \mathrm{E}+00$ & $7.2 \mathrm{E}+00$ & $10 \%$ \\
\hline Freshwater ecotoxicity (Fetx, CTUe) & $1.4 \mathrm{E}+04$ & $8.0 \mathrm{E}+03$ & $1.4 \mathrm{E}+04$ & $1.4 \mathrm{E}+04$ & $1.4 \mathrm{E}+04$ & $1.4 \mathrm{E}+04$ & $1.4 \mathrm{E}+04$ & $2 \%$ \\
\hline $\begin{array}{l}\text { Marine ecotoxicity } \\
(\text { Metx, kg 1,4-DCB eq) }\end{array}$ & $4.7 \mathrm{E}+00$ & $5.7 \mathrm{E}+01$ & $3.5 \mathrm{E}+00$ & $3.5 \mathrm{E}+00$ & $3.4 \mathrm{E}+00$ & $3.8 \mathrm{E}+00$ & $2.5 \mathrm{E}+00$ & $27 \%$ \\
\hline $\begin{array}{l}\text { Freshwater eutrophication } \\
\text { (FE, kg P eq) }\end{array}$ & $9.1 \mathrm{E}-02$ & $1.9 \mathrm{E}+00$ & $5.1 \mathrm{E}-02$ & $5.2 \mathrm{E}-02$ & $5.1 \mathrm{E}-02$ & $5.1 \mathrm{E}-02$ & $4.3 \mathrm{E}-02$ & $15 \%$ \\
\hline Marine eutrophication (ME, kg N eq) & $2.3 \mathrm{E}+01$ & $1.2 \mathrm{E}+01$ & $2.3 \mathrm{E}+01$ & $2.3 \mathrm{E}+01$ & $2.3 \mathrm{E}+01$ & $2.3 \mathrm{E}+01$ & $2.2 \mathrm{E}+01$ & $1 \%$ \\
\hline $\begin{array}{l}\text { Terrestrial ecotoxicity } \\
\text { (Tetx, kg 1,4-DCB eq) }\end{array}$ & $1.8 \mathrm{E}+00$ & $1.1 \mathrm{E}+01$ & $1.5 \mathrm{E}+00$ & $1.5 \mathrm{E}+00$ & $1.5 \mathrm{E}+00$ & $1.5 \mathrm{E}+00$ & $8.5 \mathrm{E}-01$ & $44 \%$ \\
\hline $\begin{array}{l}\text { Terrestrial acidification } \\
\text { (TA, kg SO2 eq) }\end{array}$ & $1.4 \mathrm{E}+01$ & $3.7 \mathrm{E}+02$ & $5.9 \mathrm{E}+00$ & $6.4 \mathrm{E}+00$ & $6.5 \mathrm{E}+00$ & $5.9 \mathrm{E}+00$ & $5.3 \mathrm{E}+00$ & $10 \%$ \\
\hline Fossil depletion (FD, kg oil eq) & $6.6 \mathrm{E}+02$ & $1.7 \mathrm{E}+04$ & $2.9 \mathrm{E}+02$ & $3.2 \mathrm{E}+02$ & $2.9 \mathrm{E}+02$ & $2.9 \mathrm{E}+02$ & $2.6 \mathrm{E}+02$ & $13 \%$ \\
\hline Metal depletion (MD, kg Fe eq) & $1.0 \mathrm{E}+02$ & $1.7 \mathrm{E}+03$ & $6.5 \mathrm{E}+01$ & $6.8 \mathrm{E}+01$ & $6.7 \mathrm{E}+01$ & $6.5 \mathrm{E}+01$ & $8.0 \mathrm{E}+01$ & $-23 \%$ \\
\hline Water depletion (WD, $\mathrm{m}^{3}$ ) & $7.1 \mathrm{E}+01$ & $1.5 \mathrm{E}+03$ & $3.8 \mathrm{E}+01$ & $3.8 \mathrm{E}+01$ & $3.8 \mathrm{E}+01$ & $3.8 \mathrm{E}+01$ & $7.2 \mathrm{E}+01$ & $-91 \%$ \\
\hline $\begin{array}{l}\text { Agricultural land occupation } \\
\left.\text { (ALO, } \mathrm{m}^{2} \mathrm{a}\right)\end{array}$ & $1.1 \mathrm{E}+04$ & $2.9 \mathrm{E}+04$ & $1.0 \mathrm{E}+04$ & $1.0 \mathrm{E}+04$ & $1.0 \mathrm{E}+04$ & $1.0 \mathrm{E}+04$ & $1.0 \mathrm{E}+04$ & $0 \%$ \\
\hline Aggregated environmental impact & $100 \%$ & $32 \%$ & $34 \%$ & $25 \%$ & $3 \%$ & $6 \%$ & & \\
\hline \multicolumn{9}{|l|}{ Economic assessment } \\
\hline Labor cost $(€)$ & 2031 & - & 1901 & 1942 & 4005 & 1901 & 1894 & $0.36 \%$ \\
\hline Inputs cost $(€)$ & 733 & - & 244 & 244 & 244 & 244 & 195 & $20.08 \%$ \\
\hline Fuel cost $(€)$ & 423 & - & 158 & 161 & 104 & 158 & 147 & $6.95 \%$ \\
\hline Gross margin $(€)$ & - & - & 20729 & 20685 & 18679 & 20729 & 20796 & $-0.32 \%$ \\
\hline Loan repayment $\left(€^{*}\right)$ & 124983 & - & - & - & - & - & - & - \\
\hline Safety margin $(€)$ & 15626 & - & - & - & - & - & - & - \\
\hline Economic performance (score) & 75 & & 60 & 60 & 45 & 60 & 66 & $-10 \%$ \\
\hline
\end{tabular}

emissions) and marine eutrophication (due to natural nitrate emissions from the soil). The contributions of PTO 2, PTO 3, and PTO 4 varied according to their surface areas, since their impact per ha differed little and had a pattern among impact categories similar to that of PTO 1.

PTO 1eco had lower impacts than PTO 1 in most categories. Terrestrial ecotoxicity decreased the most (44\%), due to the recycling panel in the first application and the change in active ingredients in the fifth application. However, some impacts were higher for PTO 1eco, such as a $91 \%$ increase in water depletion due to using more copper-based pesticides to replace CMR pesticides. Ecodesign reduced the farm's aggregated impact by $11 \%$.

\subsubsection{Economic performances of the case study}

The change in economic performances due to changing practices was determined by comparing IPE2Vit results for PTO $1+4$ to those for the ecodesigned system PTO 1 eco +4 (Table 2). PTO 3 had lower vineyard inputs and fuel costs but much higher labor cost than the other types, which resulted in much lower economic performance than those of the other types, which had similar economic performances (Table 2). Replacing herbicides with mechanical 
weed control in PTO 1eco + PTO 4 increased fuel cost but decreased labor and maintenance costs per ha, which increased the economic performance.

\subsection{Main factors that influenced ecodesign at the farm scale}

The first constraint, identified by several participants, was the risk of frost (Fig. 3). Two wind corridors were identified that, combined with specific topography, created three zones with a high risk of frost, reinforced by climate change. This topic was important, since four of the past five years had experienced severe frost events. Consequently, farmers had individually or collectively invested in and prioritized in infrastructure (i.e., wind turbines and sprinkler-irrigation systems) to protect the vineyard from frost. It showed that collective investment was possible but that the degree of investment was limited by recent climatic events.

The second constraint identified was the fragmented spatial configuration of the fields. The group defined this constraint as typical of the area due to the lack of recent land consolidation. Small and scattered fields were considered a major constraint to investment in tunnel spraying or application of organic fertilizer, which would make the workload too high. According to the workshop discussion, fields following PTO 2 appeared to be located in two zones. The farm was able to produce a second high-value wine with the protected designation of origin (PDO) label in a western zone of 7.5 ha. To reach it, however, the farmer had to travel 25 min with a tractor and implements. A southern zone of 8.5 ha was the fields acquired most recently. Further from the farm headquarters but still within the main PDO 1 area, this zone had larger fields and infrastructure to resist frost. In addition, the farm could be extended into this zone. To reach this zone, the farmer had to travel 20 min with a tractor and implements. This area provides a potential avenue for more radical changes in practices. The map helped participants identify constraints and opportunities. It also encouraged them to join the discussion, since most of them shared these constraints. These constraints clearly influenced the farm layout, recent investments, and future projects. In particular, environmental constraints influenced changes in practices.

\subsection{The ecodesigned farm}

The farmers agreed to apply the changes in practices designed for PTO 1eco to PTO 3 and PTO 4. The slope and the type of wine produced did not limit crop protection management or soil management. Soil management practices ecodesigned for PTO 1 eco involved omitting herbicide treatments on the vine row and replacing them with mechanical weeding (i.e., scraping). PTO 2 faced a challenge because the gravelly soil on which it operated was not suited for grass cover due to the high risk of water stress during vine growth, especially during dry summers. However, the farmer was reluctant to leave the soil completely bare, mechanically weeded. While interrow grass cover or chemically weeded rows provide flat and hard alleys for tractors and workers to circulate in the field, bare tilled soil causes workers discomfort and limits tractor speed. Participants also discussed future regulations that will restrict or ban the use of herbicides.
Fig. 3 Map of the pathways of technical operations (PTO) on the farm and the main factors that influence changes in practices at the farm scale. PDO protected designation of origin.

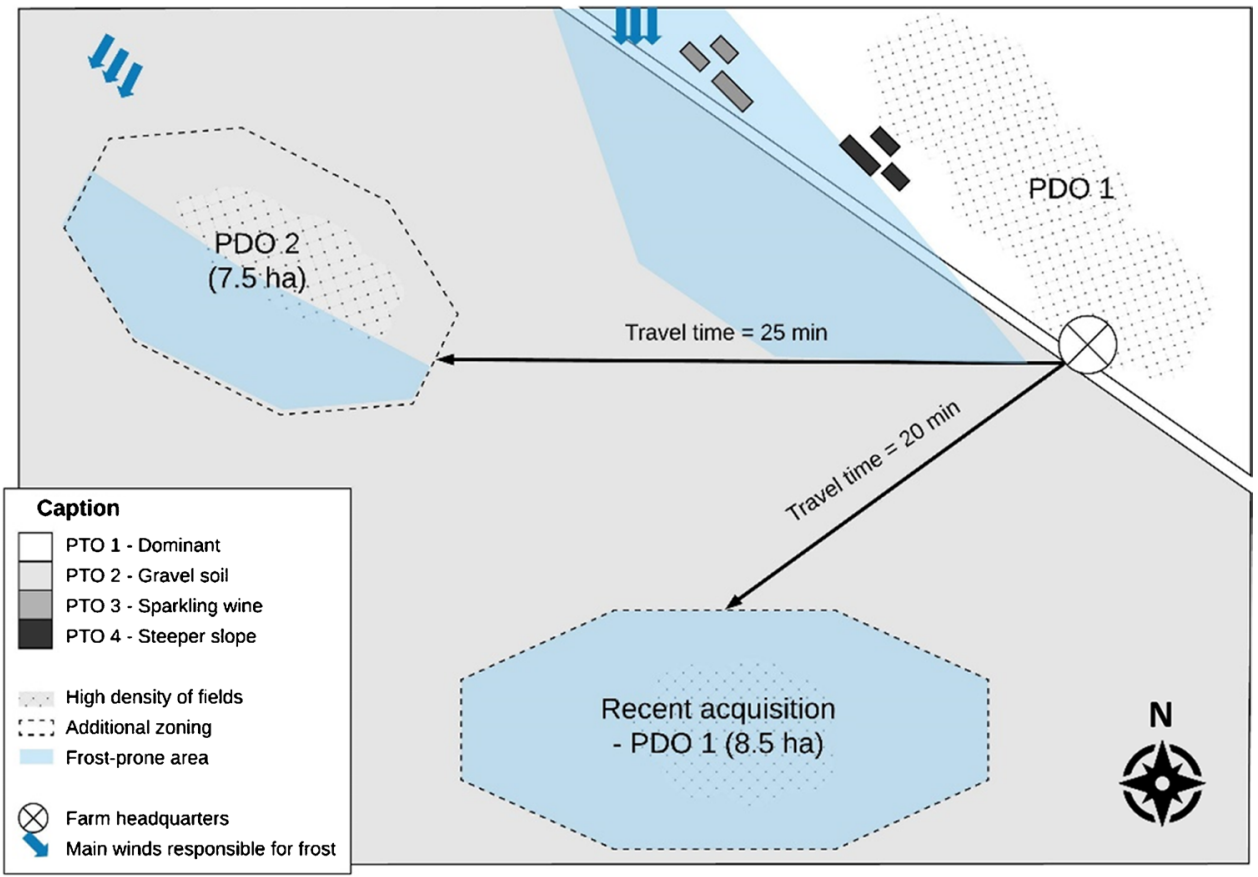


One alternative to herbicide use is green manure, which can reduce water competition between grass cover and grapevines compared to permanent grass. It contributes to maintain soil organic matter and reduces water drainage, and incorporating it into the soil in spring can prevent water stress for the grapevine. Methods for implementing it were discussed, especially because one participant had expertise in field crops. The soil management practices for PTO 2eco included green manure every third year, with organic fertilization added to avoid nitrogen stress caused by insufficient nitrogen mineralization from green manure. Completely bare soil was accepted as a temporary solution during the other 2 years until organic matter contents increased enough to allow grass cover to be planted.

\subsubsection{Environmental performance}

Environmental performances of the ecodesigned farm, calculated after the workshop, indicated that the farm's aggregated impact decreased by $4 \%$ (Fig. 4). Unlike PTO 1, PTO 3 , and PTO 4 vs. their ecodesigned counterparts, PTO 2eco had higher aggregated impact than PTO $2(+17 \%$, results not shown), due mainly to an increase in terrestrial acidification (fertilization) and water depletion (copper-based pesticides).
Fig. 4 (a) Environmental impacts and (b) economic performances, of ecodesigned types at field and farm scales compared to current situation. PTO 1 to PTO 4 pathways of technical operations; PTO 1, 2, 3,4 eco first, second, third and fourth ecodesigned pathways of technical operations. (See Table 2 for the definition of the impact categories' acronyms).
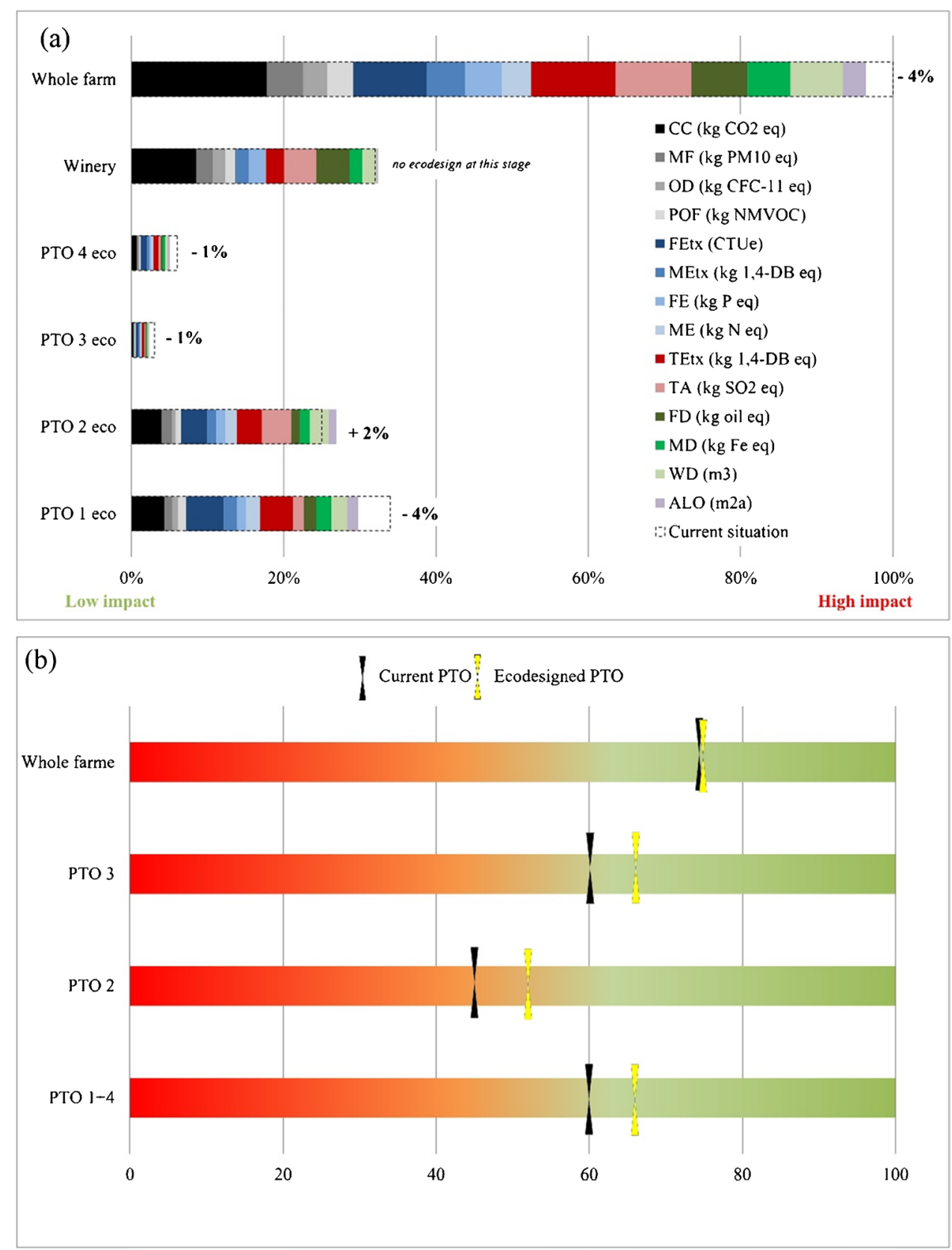


\subsubsection{Economic performance}

The changes in practices also increased the economic performance at the field scale of the four PTO present on the farm (Fig. 4). The overall economic performance of the initial and ecodesigned scenarios was presented to participants on a graduated scale that helps to visualize the influence of ecodesign on economic performance at field and farm scales (Fig. 4).

The effects of changes in practices on economic performance were clear for the three pathways of technical operations (PTO 1+4, PTO 2, and PTO 3). For PTO $1+\mathrm{PTO} 4$ and PTO 3, changes in soil maintenance practices included replacing chemical weeding on grapevine rows with mechanical weeding. These changes were combined with using a non-air-assisted sprayer with recycling panels instead of a pneumatic sprayer to apply the first two treatments. Besides decreasing the doses, it also decreased maintenance, labor, and fuel costs, which increased the gross margin per ha and thus the overall economic performance (by $10 \%$ and $15.5 \%$ for PTO 1+4 and PTO 3, respectively). In PTO 2, these changes, in addition to the changes in fertilization practices, increased the overall economic performance by $10 \%$.

At a practical level, these increases in field-scale economic performance can reassure and encourage winegrowers to adopt more environmentally friendly techniques, even though overall economic performance at the farm scale remained the same due to the investments required for these changes (Fig. 4).

\subsection{Analysis of farm ecodesign workshop}

Ecodesign at the farm scale has advantages and disadvantages compared to ecodesign at the field scale (Rouault et al. 2020), and ecodesign itself faces remaining challenges in the agricultural sector. Using the typology of farm activities helped to simplify the complexity of the farm by defining a small number of types to represent the diversity of practices and their environmental performances. The typology's systemic view encouraged farmers to identify the main constraints at the farm scale. In our case study, they identified the soil type in PTO 2 as the main constraint for changing soil management practices. Farmers explained why they could not apply the same soil management practices as those of the dominant type (PTO 1) and thus described their implicit objectives: to decrease total workload and ensure high quality of work for employees. The diversity of wine produced and the variation in topography did not appear to be systemic influencing factors in this situation, and they prompted few changes. The remaining difficulty associated with using the typology for environmental assessment of farms was that the changes proposed were limited by perennial practices. We choose to focus on annual practices as they are responsible for a large part of impacts and are the most discussed practices between farmers and advisors. For perennial crops however, field characteristics such as row spacing and grape variety define a set of constraints, which decreases the options for ecodesign of annual practices. To enlarge the opportunity of change, this study showed that perennial practices need to be challenged at some point, even if focus is put on annual practices. Both selected environmental and economic assessment tools used in this study are suited to do so.

Using a map helped to identify environmental and organizational constraints that influence ecodesign options. It also helped to identify dynamics at the farm scale, such as for the recently acquired field (Fig. 3). The scale of the map raised two main issues. First, the 120 fields on the case study farm were spread over $60 \mathrm{~km}^{2}$, which decreased the ability to identify less common constraints (e.g., direction of vine rows, electric poles, stone walls) that affected a given field. This constraint, which influences the choice of machinery and working time at the farm scale, would have less influence if the fields were near the farm. It highlighted that the spatial distribution of fields is a major constraint for changes in practices. Second, the map was designed using the information that the farmer provided about the location of fields. Without information about neighboring fields, supra-field practices cannot be discussed, such as collective mating disruption to manage bunch worms or collective manure spreading. However, these practices are highly relevant in agroecology (Gary et al. 2017). This difficulty was reinforced by the small size of the workshop group, which did not include all farmers in the area. This was due to the workshop format, which limited the number of participants to 4-8 per case study, and the requirement that participants attend three half-day workshops.

The participatory dimension of the process of ecodesign allowed to enrich the reflexion of the owner of the farm that was taken as study case. He could benefit from suggestions from the other winegrowers, and several proposals were discussed. However, he also opposed some possible changes proposed by the group to improve environmental performance, especially concerning soil management. Indeed he refused replacement of herbicides by soil tillage because of social aspects like the comfort of walking in the vineyard for the workers: as workers are difficult to find at that period in this region for manual work in vineyards, he wanted to secure the presence of his team. The group pushed the farmer to rationalize its position which globally led to an increase of the shared knowledge. New ideas also emerged from the discussion like the possibility of a collective organization of organic fertilization supply in a part of the farm territory, which could allow the winegrower to change more easily his soil management practices for grass covered soil in this area by partly compensating the competition for nitrogen 
by the grass, and increase the water retention capacity of the soil by increasing soil organic matter. Collective discussion about this case also helped the other participants gain a new understanding of environmental impact of their own practices and identify possible solutions to decrease it at the different scales treated in the workshop session.

This study shows for the first time that reparcelling could contribute to ecological transition as the spatial distribution of fields can be considered a constraint to the development of agroecological practices in a fragmented vineyard as the French one. Compared to workshops at the field scale, this farm-scale workshop encouraged greater involvement of all participants because the simple types of pathway of technical operations proposed, as well as the environmental and organizational constraints, were shared more easily than individual management choices at the field scale. In addition, discussing changes at the farm scale prompted the group to outline expected pathways for changes in practices and to gradually address all difficulties raised during the ecodesign process. This could be particularly useful for developing a step-by-step design approach (Meynard et al. 2012). These gradual approaches should involve additional stakeholders to address landscape-scale and regulatory restrictions that are unavoidable when considering changes in practices at the field scale (Moneyron et al. 2017).

Evaluating the environmental performance of changes in practices encourages winegrowers to adopt these practices because it provides a degree of availability and transparency to environmental data. Winegrowers are also aware that adopting these environmental practices meets the requirements of consumers who want higher-quality wine with no pesticide residues. However, this adoption remains rational because it depends on the desired profitability, productivity, and assumed risks. To this end, implementing economic instruments to combine economic and environmental performances was necessary to support farmers in "global" decisions involved in changing practices in the short and medium term and to respond to the requirements and characteristics of their farms. Here, we confirmed that such assessment increasingly highlights the economic difficulties of winemakers (Chiffoleau 2012). We show for the first time the interest to quantify the influence of a farm's environmental practices on its economic performance to reduce the perception of risk and promote adoption of these practices.

\subsection{Limitations and perspectives}

The use of LCA in this study brought many interests as multicriteria and life cycle approach. However, some limitations remain concerning its application to agriculture like the quality of impact assessment of copper compounds (Peña et al. 2018) and the absence of consideration of the degradation molecules of pesticides which could have an influence on the environmental performance results in this study. The environmental assessment by LCA at farm scale will gain additional interest if non-productive areas of the farm are included considering their benefits on biodiversity; this demands the development of new indicators and should be the object of future works. The farm-scale ecodesign process integrating economic performance results did not include transitional costs, which are often considered to limit changes in practices (Naidoo and Adamowicz 2006). This could be an interesting perspective for future developments of the approach. The economic and environmental assessments were conducted on separate tools; a combined tool integrating the two approaches would ease the process of evaluation in such workshops. This farm-scale workshop framework also opens perspectives for its adaptation to a regional-scale approach like PDO to support practice change in collective set of rules, for example. Concerning the design of the approach, it was done by the research team in interaction with the extension officers; in future sessions, some winegrowers could be involved in the design process of designing the workshops. Finally, one of the difficulties of such participative ecodesign session in viticulture is the enrolment of winegrowers as they are very busy because of the multiplicity of their tasks. This aspect has to be anticipated in future workshops to ensure a sufficient number of participants.

\section{Conclusion}

We presented a methodological framework to address changes in practices at field and farm scales with the participation of farmers and their agricultural advisors. This framework combines a typology approach with economic and environmental assessment tools in a participatory workshop. Applying this framework to the ecodesign of a vineyard showed that some mechanisms can be addressed only at the farm scale, since production factors (e.g., revenue, labor) limit the degree to which practices can be changed. While at field scale technical and economic constraints were often opposed, we could witness a shift from the farmer hosting the case study as he exposed his implicit objectives being to decrease total workload and ensure high quality and comfort of work for employees and himself. Combining economic and environmental assessments addressed these limits. Though we did not specifically measure the farmers' risk perception towards the introduction of ecological innovations-due to our complex multidisciplinary methodological approach - we can underline the use of the Ipe2vit tool that allowed farmers to get a better understanding of the economic implications of their technical options. The map increased the involvement of workshop participants and helped them better recognize their own situations. The group 
members could share their own tips and argument to answer difficulties raised within the study case and could also in return apply solution to their own farms. Changing the scale from field to farm and broadening the assessment dimension from only the environment to include economics generated diverse perspectives: development for better practice change assessment of i) a combined tool including environmental and economic assessment, ii) additional indicators for effect on biodiversity, iii) inclusion of non productive areas of the farm in the assessment, iv) inclusion of transitional costs in the economic assessment. Here, we show for the first time the need to quantify the influence of a farm's environmental practices on its economic performance to reduce the perception of risk and facilitate adoption of these practices. By doing so, and thanks to the participatory approach producing exchanges of points of views with his pairs, the farmer was keener to consider middle- and long-term solutions such as increasing soil organic matter by introducing green manure. The collective discussion was also the opportunity for the other participants to benefit from the discussion about the case for their reflection concerning their own practices. This framework could be used at the regional scale to support collective changes in practices, such as within a PDO region. Finally, winegrowers and/or agricultural advisors can use the tools to inform changes in practices in a step-by-step design approach.

Acknowledgements The authors thank S. Julien of USC GRAPPE; ESA-INRAE; X. Lozupone and G. Pain of UMR BAGAP, INRAEESA for their contributions; the wine growers who took part in the workshops, and the one who shared data on his farm; as well as the extension officers Q Gaufreteau of Robert et Marcel Cooperative and N. Daspres of Terra Vitis.

Authors' contributions All authors contributed to the study conception and design. Material preparation, data collection, and analysis were performed by Aurélie Perrin, Magdalena Czyrnek-Delêtre, Maha Ben Jaballah, and Christel Renaud-Gentié. The first draft of the manuscript was written by Aurélie Perrin, and all authors commented on previous versions of the manuscript. All authors read and approved the final manuscript.

Funding This study formed part of the Eco3Vic project, funded by ADEME (French Environment \& Energy Management Agency) and led by Frédérique Jourjon of USC GRAPPE, ESA-INRAE, the AVATEC project funded by FEDER and the SCALE project funded by Université Bretagne Loire.

Data availability Data sharing is not applicable to this article as no datasets were generated or analyzed during the current study.

\section{Declarations}

Ethics approval This study involved human participants for a workshop about viticulture. It didn't include any health-related experiment or private data questions, thus it is not concerned by the Helsinki declaration on medical research ethical questions. The data published about the winegrower's farm were anonymised for their publication.
Informed consent Verbal informed consent was obtained from all individual participants included in the study.

Conflict of interests The authors have no conflicts of interest to declare that are relevant to the content of this article. All authors certify that they have no affiliations with or involvement in any organization or entity with any financial interest or non-financial interest in the subject matter or materials discussed in this manuscript. The authors have no financial or proprietary interests in any material discussed in this article.

Open Access This article is licensed under a Creative Commons Attribution 4.0 International License, which permits use, sharing, adaptation, distribution and reproduction in any medium or format, as long as you give appropriate credit to the original author(s) and the source, provide a link to the Creative Commons licence, and indicate if changes were made. The images or other third party material in this article are included in the article's Creative Commons licence, unless indicated otherwise in a credit line to the material. If material is not included in the article's Creative Commons licence and your intended use is not permitted by statutory regulation or exceeds the permitted use, you will need to obtain permission directly from the copyright holder. To view a copy of this licence, visit http://creativecommons.org/licenses/by/4.0/.

\section{References}

Alem H, Lien G, Hardaker JB (2018) Economic performance and effiency determinants of crop-producing farms in Norway. Int J Product Perform Manag 67(9):1418-1434. https://doi.org/10. 1108/IJPPM-01-2018-0026

Asfaw D, Neka M (2017) Factors affecting adoption of soil and water conservation practices: the case of Wereillu Woreda (District), South Wollo Zone, Amhara Region, Ethiopia. Int Soil Water Conserv Res 5(4):273-279. https://doi.org/10.1016/j.iswcr. 2017.10.002

Beauchet S (2016) Evaluation multicritère d'itinéraires techniques viticoles associant l'évaluation environnementale par Analyse du Cycle de Vie avec l'évaluation de la qualité du raisin. Contribution au choix des pratiques pour une amélioration des itinéraires techniques viticoles

Beauchet S, Rouault A, Thiollet-Scholtus M, Renouf M, Jourjon F, Renaud-Gentié C (2019) Inter-annual variability in the environmental performance of viticulture technical management routes-a case study in the Middle Loire Valley (France). Int J Life Cycle Ass 24(2):253-265. https://doi.org/10.1007/ s11367-018-1516-y

Ben Jaballah M, Ghali M, Renaud-Gentié C (2019) IPE2Vit: innovative double scale tool for economic impact of changes in wine practices. Paper presented at the The 13th Annual American association of wine economics (AAWE) Conference Vienna, Austria July 2019

Blasi E, Passeri N, Franco S, Galli A (2016) An ecological footprint approach to environmental-economic evaluation of farm results. Agric Syst 145:76-82

Boussemart J-P, Dervaux B (1994) Diagnostic de l'efficacité productive par la méthode DEA. Application à des élevages porcins. Cahiers d'Economie et de Sociologie Rurales (CESR) 31 (905-2016-70232):43-58

Calsamiglia S, Astiz S, Baucells J, Castillejos L (2018) A stochastic dynamic model of a dairy farm to evaluate the technical and economic performance under different scenarios. J Dairy Sci 101(8):7517-7530 
Chiffoleau Y (2012) Circuits courts alimentaires, dynamiques relationnelles et lutte contre l'exclusion en agriculture. Économie Rurale Agricultures, Alimentations, Territoires 332:88-101

Christ KL, Burritt RL (2013) Critical environmental concerns in wine production: an integrative review. J Clean Prod 53:232-242. https://doi.org/10.1016/j.jclepro.2013.04.007

Czyrnek-Delêtre MM, Jourjon F, Perrin A, Renaud-Gentié C, van der Werf HM (2018) From the field to the farm-scaling up life cycle assessment towards eco-design at farm-level. Paper presented at the LCA Food 2018 and LCA AgriFood Asia, Bangkok, Thailand, 17-19 October 2018

Delmotte S, Barbier JM, Ripoche A, Gary C (2009) A multiple criteria assessment approach for evaluating the sustainability of innovative cropping systems in viticulture. In: 16. International Symposium GiESCO

European Union (2009) Directive 2009/125/EC of the European Parliament and of the Council of 21 October 2009, establishing a framework for the setting of ecodesign requirements for energyrelated products, Official Journal of the European union, L285, volume 52, 31/10/2009

French-ministry-of-agriculture (2021) Le plan ecophyto qu'est-ce que c'est? https://agriculture.gouv.fr/le-plan-ecophyto-quest-ce-quecest. Accessed 04/22/2021 2021

Gary C, Metral R, Metay A, Garcia L, Mérot A, Smits N, Wéry J (2017) Towards an agroecological viticulture: advances and challenges. In: Proceedings of the 20th GiESCO International Meeting, pp 1122-1127

Goedkoop M, Heijungs R, Huijbregts M, De Schryver A, Struijs J, Van Zelm R (2009) ReCiPe 2008: A life cycle impact assessment method which comprises harmonised category indicators at the midpoint and the endpoint level.: Report I: Characterisation. A report to the Netherlands Ministry of Housing, Spacial Planning and the Environment (VROM)

Guillou M, Guyomard H, Huyghes C, Peyraud J-L (2013) Vers des agricultures doublement performantes pour concilier compétitivité et respect de l'environnement, propositions pour le Ministre

Gullino P, Larcher F (2013) Integrity in UNESCO World Heritage Sites. A comparative study for rural landscapes. J Cult Herit 14(5):389-395. https://doi.org/10.1016/j.culher.2012.10.005

Herrero-Hernández E, Simón-Egea AB, Sánchez-Martín MJ, Rodríguez-Cruz MS, Andrades MS (2020) Monitoring and environmental risk assessment of pesticide residues and some of their degradation products in natural waters of the Spanish vineyard region included in the Denomination of Origin Jumilla. Environ Pollut 264:114666. https://doi.org/10.1016/j.envpol.2020.114666

Jourjon F, Chou H-C, Gezart A, Kadison AE, Martinat L, Pomarici E, Vecchio R (2016) Wineries evaluation of costs and benefits of sustainability certification program: the case of Terra Vitis in France. Recent Patents Food Nutr Agric 8(2):138-147. https://doi. org/10.2174/2212798408666160524141500

Lacombe C, Couix N, Hazard L (2018) Designing agroecological farming systems with farmers: a review. Agric Syst 165:208-220. https://doi.org/10.1016/j.agsy.2018.06.014

Liu T, Bruins RJ, Heberling MT (2018) Factors influencing farmers' adoption of best management practices: a review and synthesis. Sustainability 10(2):432

Mackie KA, Müller T, Kandeler E (2012) Remediation of copper in vineyards - a mini review. Environ Pollut 167:16-26. https://doi. org/10.1016/j.envpol.2012.03.023

Martin G, Martin-Clouaire R, Duru M (2013) Farming system design to feed the changing world. A review. Agron Sustain Dev 33(1):131-149. https://doi.org/10.1007/s13593-011-0075-4

Martínez-Casasnovas JA, Guevara Bonilla M, Ramos M (2012) Multitemporal analysis of sediment yield caused by hydric erosion in a basin of the Anoia-Penedès vineyard region (NE Spain).
Cuadernos de Investigación Geográfica 38:95-114. https://doi. org/10.18172/cig.1277

Meynard J-M, Dedieu B, Bos AB (2012) Re-design and co-design of farming systems. An overview of methods and practices. In: Farming Systems Research into the 21st century: The new dynamic. Springer, pp 405-429

Moneyron A, Lallemand JF, Schmitt C, Perrin M, Soustre-Gacougnolle I, Masson JE (2017) Linking the knowledge and reasoning of dissenting actors fosters a bottom-up design of agroecological viticulture. Agron Sustain Dev 37(5):41

Naidoo R, Adamowicz WL (2006) Modeling opportunity costs of conservation in transitional landscapes. Conserv Biol 20(2):490-500

Nazzaro C, Marotta G, Rivetti F (2016) Responsible innovation in the wine sector: a distinctive value strategy. Agric Agric Sci Procedia 8:509-515. https://doi.org/10.1016/j.aaspro.2016.02.058

Paiola A, Assandri G, Brambilla M, Zottini M, Pedrini P, Nascimbene J (2020) Exploring the potential of vineyards for biodiversity conservation and delivery of biodiversity-mediated ecosystem services: a global-scale systematic review. Sci Total Environ 706:135839. https://doi.org/10.1016/j.scitotenv.2019.135839

Peña N, Antón A, Kamilaris A, Fantke P (2018) Modeling ecotoxicity impacts in vineyard production: addressing spatial differentiation for copper fungicides. Sci Total Environ 616-617:796-804. https://doi.org/10.1016/j.scitotenv.2017.10.243

Perrin A, Basset-Mens C, Huat J, Gabrielle B (2017) The variability of field emissions is critical to assessing the environmental impacts of vegetables: A Benin case-study. J Clean Prod 153:104-113. https://doi.org/10.1016/j.jclepro.2017.03.159

Pompermaier A, Varela ACC, Fortuna M, Mendonça-Soares S, Koakoski G, Aguirre R, Oliveira TA, Sordi E, Moterle DF, Pohl AR, Rech VC, Bortoluzzi EC, Barcellos LJG (2021) Water and suspended sediment runoff from vineyard watersheds affecting the behavior and physiology of zebrafish. Sci Total Environ 757:143794. https://doi.org/10.1016/j.scitotenv.2020.143794

Renaud-Gentié C, Dijkman TJ, Bjørn A, Birkved M (2014) Modeling pesticides emissions for Grapevine LCA: adaptation of Pest-LCI model to viticulture. In: 9th International Conference on Life Cycle Assessment in the Agri-food Sector. ACLCA

Renouf MA, Renaud-Gentié C, Perrin A, van der Werf HMG, Kanyarushoki C, Jourjon F (2018) Effectiveness criteria for customised agricultural life cycle assessment tools. J Clean Prod 179:246-254. https://doi.org/10.1016/j.jclepro.2017.12.170

Rouault A (2019) Développement méthodologique pour la mise en oeuvre d'une démarche participative d'éco-quali-conception appliquée aux systèmes de production viticoles. Développement méthodologique pour la mise en oeuvre d'une démarche participative d'éco-quali-conception appliquée aux systèmes de production viticoles., $\mathrm{PhD}$ thesis. L'UNIVERSITE D'ANGERS, COMUE UNIVERSITE BRETAGNE LOIRE, Angers

Rouault A, Beauchet S, Renaud-Gentié C, Jourjon F (2016) Life Cycle Assessment of viticultural technical management routes (TMRs): comparison between an organic and an integrated management route. OENO One 50(2). https://doi.org/10.20870/oeno-one.2016. 50.2 .783

Rouault A, Perrin A, Renaud-Gentié C, Julien S, Jourjon F (2020) Using LCA in a participatory eco-design approach in agriculture: the example of vineyard management. Int J Life Cycle Ass 25(7):1368-1383. https://doi.org/10.1007/s11367-019-01684-w

Roy P, Nei D, Orikasa T, Xu Q, Okadome H, Nakamura N, Shiina T (2009) A review of life cycle assessment (LCA) on some food products. J Food Eng 90(1):1-10. https://doi.org/10.1016/j.jfood eng.2008.06.016

Rugani B, Vázquez-Rowe I, Benedetto G, Benetto E (2013) A comprehensive review of carbon footprint analysis as an extended environmental indicator in the wine sector. J Clean Prod 54:61-77. https://doi.org/10.1016/j.jclepro.2013.04.036 
Sala S, Ciuffo B, Nijkamp P (2015) A systemic framework for sustainability assessment. Ecol Econ 119:314-325. https://doi.org/10. 1016/j.ecolecon.2015.09.015

Stanco M, Lerro M (2020) Consumers' preferences for and perception of CSR initiatives in the wine sector. Sustainability 12(13):5230

Tait P, Saunders C, Dalziel P, Rutherford P, Driver T, Guenther M (2019) Estimating wine consumer preferences for sustainability attributes: a discrete choice experiment of Californian Sauvignon blanc purchasers. J Clean Prod 233:412-420. https://doi.org/10. 1016/j.jclepro.2019.06.076 van der Werf HMG, Knudsen MT, Cederberg C (2020) Towards better representation of organic agriculture in life cycle assessment. Nat Sustain 3(6):419-425. https://doi.org/10.1038/s41893-020-0489-6

Winkler KJ, Viers JH, Nicholas KA (2017) Assessing ecosystem services and multifunctionality for vineyard systems. Front Environ Sci 5 (15). https://doi.org/10.3389/fenvs.2017.00015

Publisher's Note Springer Nature remains neutral with regard to jurisdictional claims in published maps and institutional affiliations. 